31 Didier A, Cazals Y, Aurousseau C. Brainstem connections of the anterior and posterior parts of the saccule of the guinea pig. Acta Otolarmol (Stockh) 1987:104.385-91.

32 Marsden CD, Merton PA, Morton HB. Servo action in the human thumb. $₹$ Physiol 1976;257:1-44.

33 Marsden CD, Rothwell JC, Day BL. Long-latency automatic responses to muscle stretch in man: origin and matic responses to muscle stretch in
function. Adv Neurol 1983;39:509-39.

34 Matthews PBC. Observations on the automatic compensation of reflex gain on varying the pre-existing level of motor discharge in man. F Physiol 1986;374:73-90.

35 Guitton D, Kearney RE, Werely N, Peterson BW. Visual, vestibular and voluntary contributions to human head stabilization. Exp Brain Res 1986;64:59-69.

36 Gresty $M$ (1987) Stability of the head: studies in normal subjects and in patients with labyrinthine disease, head tremor, and dystonia. Mov Disord 1987; 2:165-85.
37 Bronstein AM. Evidence for a vestibular input contributing to dynamic head stabilization in man. Acta Otolaryngol (Stockh) 1988;105:1-6.

38 Gernandt BE. Vestibular mechanisms. In: Magoun HW, ed. Handbook of physiology, section 1: neurophysiology. Washington: American Physiological Society 1959;1: 549-64.

39 Holmes G. Introduction to clinical neurology. Edinburgh: Livingstone, 1952:139-40.

40 Halmagyi GM, Curthoys IS, Brandt $T$, Dieterich $M$ Ocular tilt reaction: clinical sign of vestibular lesion. Acta Otolaryngol (Stockh) 1991;481 (suppl):47-50.

41 Bronstein AM, Rudge $P$. The vestibular system in abnor$\mathrm{mal}$ head postures and spasmodic torticollis. Adv Neurol 1988;50:493-500.

42 Smith PF, Curthoys IS. Mechanisms of recovery following unilateral labyrinthectomy: a review. Brain Res Rev $1989 ; 14: 155-80$

\section{Von Monakow and Diaschisis}

For much of the 19th century, clinical localisation rested on the belief that geometric localisation produced signs dependent on functions derived from that focal area. In 1967 Geschwind's “disconnection syndromes" highlighted the phenomenology of dysfunction at a distance. Geschwind's notions, now accepted, hark back to the work of Constantin Von Monakow (1853-1930). ${ }^{1}$ He introduced the word "diaschisis" to indicate loss of function and signs, anatomically removed from the lesion-the equivalent of Geschwind's disconnection. Von Gudden had shown him atrophy of the superior colliculus in a rabbit after removal of the contralateral eye at birth. In 1879 he removed the occipital lobes in two newborn rabbits and one year later noticed complete degeneration of the lateral geniculate nuclei.

Von Monakow described diaschisis cortico-spinalisimpaired function of spinal motor neurons due to cortical motor lesions; diaschisis associativa-cortical dysfunction due to lesions of connected areas within one hemisphere, and diaschisis commisuralis-cortical dysfunction due to lesions of the interconnected contralateral hemisphere.

He refuted the purist's notions of localisation:

The generally accepted theory according to which aphasia, agnosia, apraxia etc. are due to destruction of narrowly circumscribed appropriate praxia, gnosia, and phasia centres, must be finally discarded on the basis of more recent clinical and anatomical studies. It is just in the case of these focal symptoms that the concept of complicated dynamic disorders in the whole cortex becomes indispensable.

The verification of Von Monakow's postulates has been achieved by oxygen and glucose uptake studies, and by disordered blood flow and electrophysiology in distant sites.

The syndrome of anterior choroidal thrombosis causing contralateral hemiplegia, hemianaesthesia and hemianopia is referred to as Von Monakow's syndrome. He also wrote extensively on the cortex, microcephaly, anencephaly, and aneurysm of the vertebral artery.

Born the son of a Russian nobleman, his family fled the Franco-Prussian war, settling in Dresden, then Paris, and Zurich where they were naturalised in 1869. A huge, bearded figure with a shrill voice, he was noted, in youth, for his boisterous, eccentric behaviour. Later, he eschewed faculty meetings, and was devoted to his family and books. His famous Gehirnpathologie contained over 3000 references that he had collected personally. In later life he published three lectures, entitled: Emotions, morality and the brain. He died of "retention-uraemia" aged 77 while writing on "The value of life".

JMS PEARCE 304 Beverley Road Anlaby, Hull

1 Von Monakow C. Die lokalisation im Grosshim und der Abbau der Funktion durch kortikale Herde. Wiesbaden: Bergmann 1914. Transl. G Harris In: Pribam KH, ed. Brain and Behavior I: Mood States and Mind. Baltimore: Penguin 1969:27-36. 